\title{
Low expression of PKC $\alpha$ and high expression of KRAS predict poor prognosis in patients with colorectal cancer
}

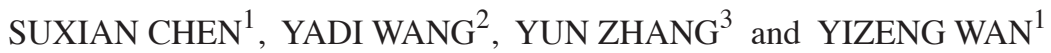 \\ Departments of ${ }^{1}$ Pathology, ${ }^{2}$ Oncology and ${ }^{3}$ Obstetrics and Gynecology, \\ The Third Affiliated Hospital of Liaoning Medical College, Jinzhou, Liaoning 121002, P.R. China
}

Received February 11, 2015; Accepted March 8, 2016

DOI: $10.3892 / \mathrm{ol} .2016 .4845$

\begin{abstract}
The current study aimed to determine the association between protein kinase $\mathrm{C} \alpha(\mathrm{PKC} \alpha)$ and Kirsten rat sarcoma viral oncogene homolog (KRAS) expression and the response to folinic acid, 5-fluorouracil and oxaliplatin (FOLFOX regimen) in patients with colorectal cancer (CRC). The protein levels of PKC $\alpha$ and KRAS were analyzed by immunohistochemistry in tissue samples from patients with $\mathrm{CRC}$ and in non-cancerous tissues, including 152 cases of colorectal adenocarcinoma, 30 cases of colorectal adenoma and 20 normal colonic mucosa samples. The association between PKC $\alpha$ and KRAS expression and clinicopathological features was analyzed. The rates of positive PKC $\alpha$ protein expression in patients with poorly, moderately and well-differentiated adenocarcinoma were $16.7 \%$ (6/36), 40.0\% (24/60), and 57.1\% (32/56), respectively $(\mathrm{P}<0.013)$. The rate of positive KRAS expression in CRC patients was significantly higher than in patients with colon adenoma and normal colon mucosa $(\mathrm{P}<0.001)$. Expression levels of KRAS were associated with the degree of differentiation of CRC $(\mathrm{P}<0.001)$. Expression of PKC $\alpha$ was negatively correlated with KRAS expression in CRC tissues. The mean progression-free survival (PFS) times in patients with high and low expression of PKC $\alpha$ were 43.9 and 38.8 months, respectively $(\mathrm{P}<0.001)$. The mean PFS times were 38.5 and 45.5 months in patients with high and low expression of KRAS, respectively $(\mathrm{P}=0.001)$. In conclusion, low PKC $\alpha$ and high KRAS expression predicted relatively poor prognosis in patients with $\mathrm{CRC}$.
\end{abstract}

\section{Introduction}

Colorectal cancer (CRC) poses a major public health issue worldwide; it is the third most common type of cancer and the second leading cause of cancer-associated mortality $(1,2)$.

Correspondence to: Dr Yizeng Wan, Department of Pathology, The Third Affiliated Hospital of Liaoning Medical College, 2 Heping Road Section 5, Linghe, Jinzhou, Liaoning 121002, P.R. China

E-mail: wangyadi2014@163.com

Key words: colorectal cancer, protein kinase $\mathrm{C} \alpha$, prognosis, Kirsten rat sarcoma viral oncogene homolog, chemotherapy
Several randomized trials of chemoradiotherapy for CRC have demonstrated improved local control and survival benefits $(3,4)$. A commonly used chemotherapy regimen for the treatment of CRC includes folinic acid, 5-fluorouracil (FU) and oxaliplatin (FOLFOX regimen); however, responses to FOLFOX vary significantly in clinical settings (5) and may be associated with expression levels of various host genes (6). To the best of our knowledge, there is no widely accepted molecular marker to predict patient response to, and outcome of, the FOLFOX regimen.

Protein kinase $\mathrm{C} \alpha(\mathrm{PKC} \alpha)$ is a member of the family of serine- and threonine-specific protein kinases and is important for numerous cellular functions, including adhesion and transformation, cell cycle progression and cell volume control (7-9). PKC $\alpha$ also regulates tissue-dependent tumor growth and progression (10). In certain circumstances, PKC $\alpha$ acts as a tumor promoter while, in others, it acts as a tumor suppressor. Overexpression of PKC $\alpha$ has been demonstrated in tissue samples of prostate, endometrial, high-grade urinary bladder and hepatocellular cancers (11-13), while downregulation of $\mathrm{PKC} \alpha$ in hematological malignancies, basal cell carcinoma and CRC has also been observed $(14,15)$. A previous study revealed that inhibition of $\mathrm{PKC} \alpha$ overcomes multidrug resistance in human CRC cells (16). However, the role of PKC $\alpha$ in patient responses to chemotherapy, particularly the FOLFOX regimen, is largely unknown.

Kirsten rat sarcoma viral oncogene homolog (KRAS) protein is a GTPase, and mutation of KRAS is an essential step in the development of various types of cancer $(17,18)$, including CRC (19). Although KRAS mutation is predictive of a poor response to panitumumab (Vectibix ${ }^{\circledR}$ ) and cetuximab (Erbitux $^{\circledR}$ ) therapy in CRC patients (20), the role of KRAS overexpression in response to the FOLFOX regimen remains to be established. Additionally, several studies have revealed that PKC $\alpha$ functionally interacts with KRAS $(21,22)$. Therefore, the present clinical study was designed to determine the association between PKC $\alpha$, KRAS expression and the response to the FOLFOX regimen in patients with CRC.

\section{Patients and methods}

Patients. The current study recruited 152 patients with colon adenocarcinoma who attended the Department of Oncology of the Third Affiliated Hospital of Liaoning Medical College 
Table I. Expression of PKC $\alpha$ and KRAS in normal colon tissue, colon adenoma and colon cancer, and its association with clinicopathological parameters.

\begin{tabular}{|c|c|c|c|c|c|c|c|c|c|}
\hline \multirow[b]{2}{*}{ Patients } & \multirow[b]{2}{*}{ Total } & \multicolumn{4}{|c|}{$\mathrm{PKC} \alpha+$} & \multicolumn{4}{|c|}{$\mathrm{KRAS}+$} \\
\hline & & $\mathrm{n}$ & $\%$ & $\chi^{2}$ & P-value & $\mathrm{n}$ & $\%$ & $\chi^{2}$ & P-value \\
\hline Colorectal cancer & 152 & 54 & 35.5 & 7.983 & 0.018 & 104 & 68.4 & 10.086 & 0.006 \\
\hline Colorectal adenoma & 30 & 16 & 53.3 & & & 14 & 46.7 & & \\
\hline Normal colon tissue & 20 & 16 & 80.0 & & & 4 & 20.0 & & \\
\hline Gender & & & & 0.010 & 0.920 & & & 0.650 & 0.420 \\
\hline Male & 72 & 26 & 36.1 & & & 46 & 63.9 & & \\
\hline Female & 80 & 28 & 35.0 & & & 58 & 72.5 & & \\
\hline Age, years & & & & 1.854 & 0.173 & & & 0.001 & 0.975 \\
\hline$<60$ & 32 & 16 & 50.0 & & & 22 & 68.8 & & \\
\hline$\geq 60$ & 120 & 38 & 31.7 & & & 82 & 68.3 & & \\
\hline $\begin{array}{l}\text { Pathological } \\
\text { differentiation }\end{array}$ & & & & 8.728 & 0.013 & & & 17.667 & $<0.001$ \\
\hline High & 56 & 30 & 53.6 & & & 26 & 46.4 & & \\
\hline Moderate & 60 & 20 & 33.3 & & & 42 & 70.0 & & \\
\hline Low & 36 & 4 & 11.1 & & & 32 & 88.9 & & \\
\hline Lymph node metastasis & & & & 2.727 & 0.099 & & & 2.129 & 0.145 \\
\hline Positive & 82 & 36 & 43.9 & & & 62 & 75.6 & & \\
\hline Negative & 70 & 18 & 25.7 & & & 42 & 60.0 & & \\
\hline Dukes' stage & & & & 2.790 & 0.248 & & & 2.492 & 0.288 \\
\hline A & 26 & 6 & 23.1 & & & 14 & 53.8 & & \\
\hline $\mathrm{B}$ & 44 & 12 & 27.3 & & & 28 & 63.6 & & \\
\hline $\mathrm{C}+\mathrm{D}$ & 82 & 36 & 43.9 & & & 62 & 75.6 & & \\
\hline
\end{tabular}

PKC $\alpha$, protein kinase C $\alpha$; KRAS, Kirsten rat sarcoma viral oncogene homolog.

(Jinzhou, China) between March 2008 and March 2011. : The inclusion criteria were as follows: i) Patients with radical tumor resection; ii) histologically diagnosed with colorectal cancer; and iii) medical record contains all clinicopathological data. The exclusion criteria were as follows: i) Severe dysfunctions of the kidney, liver, or heart; ii) severe complications following surgery, such as surgery-related intestinal fistula or stricture, or pancreatic fistula; iii) history of organ transplantation or severe renal, liver or heart diseases; and iv) lost to follow-up. Among the included patients, 72 were male and 80 were female; 56 had well-differentiated adenocarcinoma, 60 had moderately-differentiated adenocarcinoma and 36 had poorly-differentiated adenocarcinoma. Lymph node metastasis was present in 82 cases. According to Dukes' staging method (23), 26, 44, 58 and 24 patients were of stages A, B, C and $\mathrm{D}$, respectively. There were 86 patients whose tumors had invaded the serosa.

In addition, 20 normal colorectal mucosa samples were obtained from resected specimens, and were taken from $\geq 10 \mathrm{~cm}$ away from the tumor margins in the mucous membranes; the control specimens were pathologically confirmed to be free of cancer cell invasion. All fresh tissue samples were fixed in $10 \%$ formalin and embedded in paraffin. Serial $4-\mu \mathrm{m}$ sections were cut and underwent hematoxylin and eosin and immunohistochemical (IHC) staining. All patients were examined by computed tomography, magnetic resonance imaging or other scans (such as chest X-ray) to monitor for tumor recurrence or metastasis. Specimens were surgically removed and pathologically confirmed.

All patients were treated with preoperative radiotherapy and chemotherapy. To be eligible for chemotherapy, patients were required to have liver and kidney functions in the normal ranges [serum aminotransferase, $\leq 100 \mathrm{IU}$; and urine creatinine level, $\leq 198.9 \mu \mathrm{mol} / 1$ (men) or $\leq 159.15 \mu \mathrm{mol} / 1$ (women)], normal electrocardiogram findings and a Karnofsky performance status (24) score of $\geq 70$. The study was approved by the review board of the hospital, and informed consent was obtained from each participant.

Chemotherapeutic regimen. Prior to participating in the study, written informed consent was obtained from each patient. The chemotherapeutic regimen, FOLFOX6, included oxaliplatin $\left[100 \mathrm{mg} / \mathrm{m}^{2}\right.$, intravenous drops (IVgtt), day 1], calcium folinate $\left(200 \mathrm{mg} / \mathrm{m}^{2}, \mathrm{IVgtt}\right.$, days $\left.1-2\right)$ and $5-\mathrm{FU}\left(400 \mathrm{mg} / \mathrm{m}^{2}\right.$ IV on day 1 ; and $2,400 \mathrm{mg} / \mathrm{m}^{2}$, continuous IV for $46 \mathrm{~h}$ ) as part of an mFOLFOX6 regimen. The regimen was repeated every 3-4 weeks. The Response Evaluation Criteria in Solid Tumors (25) were used to evaluate each patient's status following 6 cycles of treatment. Follow-up was performed until July 31st, 2012. 

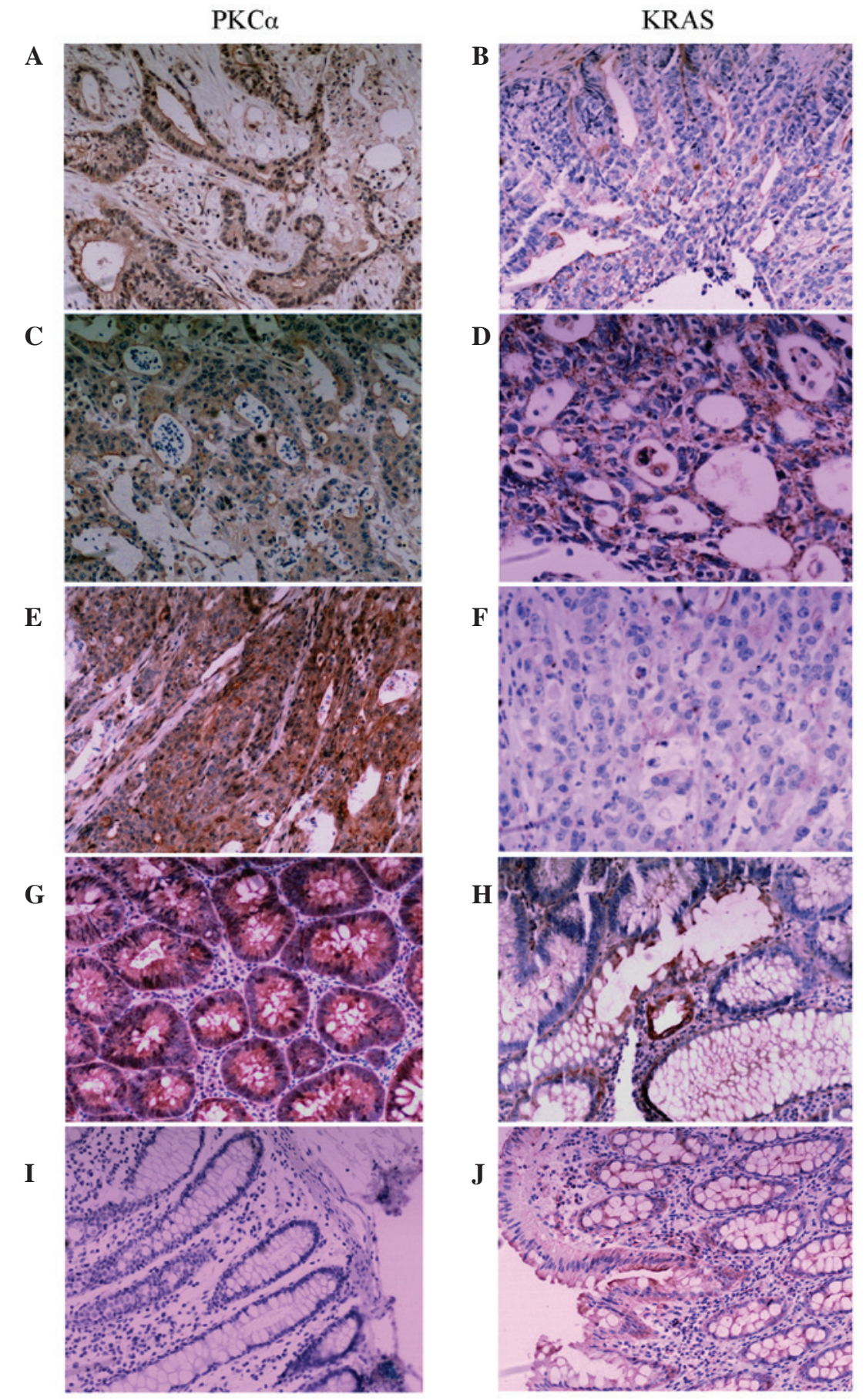

Figure 1. Representative immunohistochemistry images of PKC $\alpha$ (left column) and KRAS (right column) staining in adenocarcinoma, colon adenoma and normal colon mucosa. (A and B) Minimally-differentiated adenocarcinoma; (C and D) moderately-differentiated adenocarcinoma; (E and F) well-differentiated adenocarcinoma; (G and H) colon adenoma; (I and J) normal colon mucosa. PKC $\alpha$, protein kinase $\mathrm{C} \alpha$; KRAS, Kirsten rat sarcoma viral oncogene homolog.

Evaluation and survival records. The initial date of treatment was set as the starting point for survival analysis. Progression-free survival (PFS) and overall survival (OS) were recorded and analyzed.

IHC assay. Rabbit anti-human PKC $\alpha$ polyclonal antibody (\#BA1360; dilution, 1:200) and rabbit anti-human KRAS polyclonal antibody (\#BA4371; dilution, 1:150) were purchased from Wuhan Boster Biological Technology, Ltd. (Wuhan, China). IHC analyses of the paraffin-embedded tissue sections were performed using a standard protocol. Paraffin-embedded tissue sections were deparaffinized in xylene for $2 \times 10$ min each and rehydrated in a graded series of ethanol (100-50\%). The sections were cooked in a high pressure cooker in citric acid buffer (pH 6.0) for 5 min and subsequently incubated in 3\% $\mathrm{H}_{2} \mathrm{O}_{2}$ in phosphate-buffered saline (PBS) for $10 \mathrm{~min}$ at room temperature, and then with $15 \%$ normal serum for $30 \mathrm{~min}$ in the room temperature. Subsequently, the sections were incubated with a primary antibody at $4^{\circ} \mathrm{C}$ overnight. The following day, the sections were washed three times with PBS and then incubated with the polymer helper from the DAB color reaction kit (Wuhan Boster Biological Technology, Ltd.) at $37^{\circ} \mathrm{C}$ for $10 \mathrm{~min}$. 

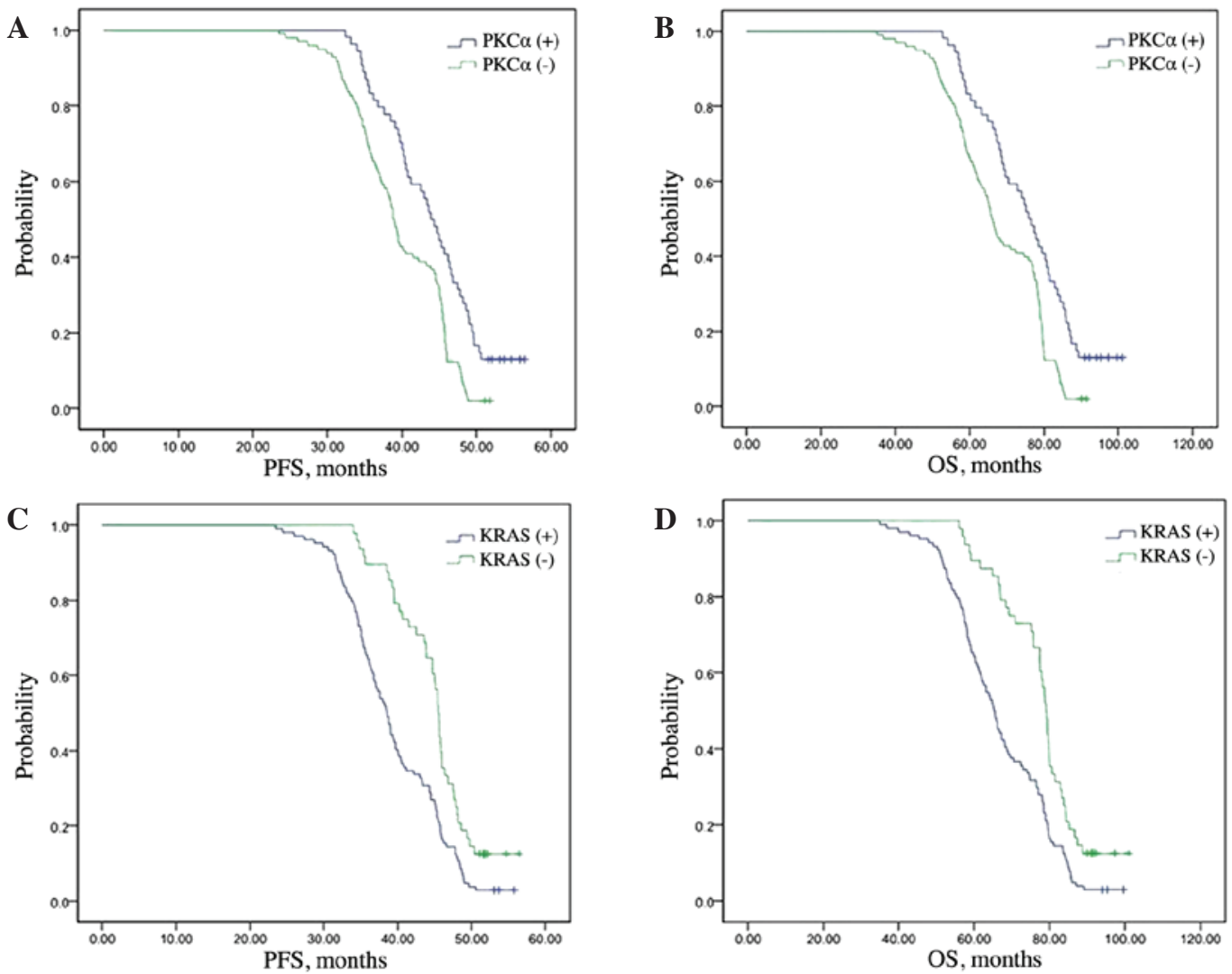

Figure 2. Survival times in different groups of patients, based on PKC $\alpha$ and KRAS expression. (A) PFS according to PKC $\alpha$ expression; (B) OS according to PKC $\alpha$ expression; (C) PFS according to KRAS expression; (D) OS according to KRAS expression. PKC $\alpha$, protein kinase C $\alpha$; KRAS, Kirsten rat sarcoma viral oncogene homolog; PFS, progression-free survival; OS, overall survival.

The sections were briefly washed with PBS three times, and further incubated with goat anti-rabbit IgG (ready for use) from the same kit at $37^{\circ} \mathrm{C}$ for $20 \mathrm{~min} .3,3^{\prime}$-diaminobenzidine was used for color reaction and the sections were counterstained with hematoxylin solution and mounted with a coverslip. The stained sections were reviewed and scored under a light microscope.

PKC $\alpha$ was expressed in the cytoplasm and cell membrane; positive signals were visible as brown granules. A staining intensity score was assigned to each sample according to the following: 0 , negative (no color); 1, weak positive (light yellow); 2 , positive (brown); 3 , strong positive (dark brown). In addition, a second score was assigned according to the percentage of positive cells: 0 , negative; $1, \leq 10 \% ; 2,11-50 \%$; $3,51-75 \%$; and $4,>75 \%$. A final score was obtained by multiplying the staining intensity score by the positive percentage score. Samples with a final score of $\geq 2$ were recorded as positive (+). KRAS was expressed in the cytoplasm and the IHC results were recorded in the same fashion as for PKC $\alpha$.

Statistical analysis. All data were analyzed using SPSS version 13.0 (SPSS, Inc., Chicago, IL, USA). Positive rates for each group were compared using a $\chi^{2}$ test. The Kaplan-Meier method was used for survival analysis. Log-rank analysis was used to identify prognostic factors and Cox regression analysis was used to identify independent prognostic factors. Pearson's correlation test was performed to analyze the association between two groups with normally distributed data. All statistical tests were two-sided probability tests and $\mathrm{P}<0.05$ was considered to indicate a statistically significant difference.
Table II. Correlation between PKC $\alpha$ and KRAS expression in patients with colorectal adenocarcinoma.

\begin{tabular}{lrrrrr}
\hline & \multicolumn{5}{c}{ KRAS, } \\
\cline { 3 - 4 } PKC $\alpha$ & Total & \multicolumn{1}{c}{+} & - & r & P-value \\
\hline+ & 54 & 20 & 34 & -0.930 & 0.002 \\
- & 98 & 84 & 14 & & \\
Total & 152 & 104 & 48 & & \\
\hline
\end{tabular}

Analyzed using Pearson's correlation test. PKC $\alpha$, protein kinase $\mathrm{C} \alpha$; KRAS, Kirsten rat sarcoma viral oncogene homolog.

\section{Results}

PKC $\alpha$ and KRAS expression in CRC and non-cancerous tissue, and association with clinicopathological parameters. PKC $\alpha$ was located in the cytoplasm and cell membrane and was observed as brown granules (Fig. 1). The rate of positive expression of PKC $\alpha$ in CRC tissues was significantly lower than that in colorectal adenoma and normal colorectal mucosa tissues $(\mathrm{P}=0.018$; Table I). KRAS immunoreactivity was observed in the cytoplasm (Fig. 1). The KRAS protein expression rate in CRC tissues was significantly higher compared with that in colon adenoma and normal colon mucosa tissues $(\mathrm{P}=0.006)$ (Table I). 
Table III. Cox multivariate survival analysis.

\begin{tabular}{|c|c|c|c|c|c|c|}
\hline Variable & $\mathrm{B}$ & SE & Wald & df & Sig. & $\operatorname{Exp}(B)$ \\
\hline Age & 0.377 & 0.226 & 2.786 & 1 & 0.095 & 1.459 \\
\hline Gender (male vs. female) & 0.187 & 0.171 & 1.196 & 1 & 0.274 & 1.205 \\
\hline Tumor differentiation (well vs. moderate vs. poor) & 0.412 & 0.220 & 3.511 & 1 & 0.061 & 1.510 \\
\hline Lymph node metastasis (positive vs. negative) & -0.032 & 0.470 & 0.005 & 1 & 0.946 & 0.969 \\
\hline Dukes' stage (A vs. B vs. C+D) & 0.741 & 0.293 & 6.397 & 1 & 0.011 & 2.099 \\
\hline PKC $\alpha(+)$ & 0.601 & 0.205 & 8.564 & 1 & 0.003 & 1.824 \\
\hline KRAS (-) & -0.672 & 0.199 & 11.428 & 1 & 0.001 & 0.511 \\
\hline
\end{tabular}

B, risk degree; SE, standard error; df, degrees of freedom; Sig., degree of significance; Exp(B), hazard ratio between groups; PKC $\alpha$, protein kinase C $\alpha$; KRAS, Kirsten rat sarcoma viral oncogene homolog.

The rates of positive $\mathrm{PKC} \alpha$ protein expression in poorly, moderately and well-differentiated adenocarcinoma were $11.1 \%$ (4/36), 33.3\% (20/60), and 53.6\% (30/56), respectively $(\mathrm{P}<0.013)$ (Table I). The positive rates of PKC $\alpha$ protein in patients of Dukes' stages A, B and C+D were 23.1\% (6/26), 27.3\% (12/44) and $43.9 \%$ (36/82), respectively. Expression of PKC $\alpha$ was not associated with gender, age, lymph node metastasis or Dukes' stage. Expression of KRAS was significantly associated with the degrees of differentiation in CRC $(\mathrm{P}<0.001)$ (Table I).

Expression of $P K C \alpha$ is negatively correlated with KRAS expression in CRC. The association between PKC $\alpha$ and KRAS expression was investigated in cancer tissues. There were 20 cases with KRAS-positive expression out of $54 \mathrm{PKC} \alpha$-positive cases, and $84 \mathrm{KRAS}$-positive cases in $98 \mathrm{PKC} \alpha$-negative cases. The difference in expression pattern was statistically significant $(\mathrm{P}=0.002$; Table II). The expression of PKC $\alpha$ was negatively correlated with KRAS expression in CRC ( $r=-0.930 ;-1 \leq r<0$, Pearson's correlation test; Table II).

Expression status of PKC $\alpha$ and KRAS predicts survival in CRC patients. A Cox multivariate survival analysis indicated that PKC $\alpha$ expression $(\mathrm{P}=0.003)$, KRAS expression $(\mathrm{P}=0.001)$ and Dukes' stage $(\mathrm{P}=0.011)$ were independent factors for predicting the prognosis of CRC patients (Table III). Kaplan-Meier curves and the log-rank test were used to analyze survival of patients. The mean durations of PFS were 43.9 and 38.8 months in the PKC $\alpha$ high-expression group and low-expression groups, respectively $(\mathrm{P}<0.001$; Fig. $2 \mathrm{~A})$. The mean $\mathrm{OS}$ times were 76.0 and 65.9 months in the $\mathrm{PKC} \alpha$ high- and low-expression groups, respectively $(\mathrm{P}<0.001 ;$ Fig. 2B). The mean durations of PFS were 38.5 and 45.5 months in the KRAS high- and low-expression groups, respectively $(\mathrm{P}=0.001$; Fig. $2 \mathrm{C})$. The mean durations of OS were 65.2 and 79.0 months in the KRAS high- and low-expression groups, respectively ( $\mathrm{P}<0.001$; Fig. 2D).

\section{Discussion}

Although surgery remains the most common treatment for CRC, $40-50 \%$ of patients undergoing only surgery ultimately relapse and succumb to metastatic disease (26). Adjuvant chemotherapy has an established role in the treatment of stage III CRC (27). The FOLFOX regimen has been widely used as an adjuvant treatment for CRC (28); however, response to the FOLFOX regimen varies between patients. To date, no clear molecular marker has been established to predict the response of patients to this regimen. Furthermore, the molecular mechanism that mediates chemoresistance to FOLFOX is largely unknown. In the present study, the expression of PKC $\alpha$ was found to be negatively correlated with KRAS expression. More importantly, the low expression of PKC $\alpha$ and high expression of KRAS independently indicated poor outcome in CRC patients treated with FOLFOX, which may have clinical implications.

PKC is widely expressed in tissues, and abnormal expression levels have been detected in numerous types of transformed cell lines and tumors (29). The role of PKC $\alpha$ in CRC is not fully understood. The mRNA (30) and protein expression $(31,32)$ of $\mathrm{PKC} \alpha$ are decreased in CRC patients. However, several reports suggest that $\mathrm{PKC} \alpha$ is upregulated in CRC patients, and that inhibiting its expression protects against multidrug resistance in human CRC cells $(11,16)$. PKC $\alpha$ also suppresses intestinal tumor formation in mice (15). In the present study, PKC $\alpha$ protein expression was significantly reduced in CRC patients, and the low expression of $\mathrm{PKC} \alpha$ predicted poor prognosis. Our results support the notion of PKC $\alpha$ as a tumor suppressor in CRC and suggest that its expression may be used to predict response to chem therapy.

The Ras gene family, including HRAS, KRAS and NRAS, has essential functions in normal tissues, including cell growth and differentiation, whereas mutated Ras proteins contribute to cancer development (33). Ras proteins function as molecular switches; once turned on, they activate growth factors and receptors, such as c-Raf and phosphoinositide 3-kinase, to promote cell proliferation and transformation. The majority of $R A S$ mutations lead to continuously activated Ras protein (11). Mutations in the Ras family of proto-oncogenes are extremely common and have been identified in $20-30 \%$ of all human tumors (34). The KRAS oncogene is mutated in $35-45 \%$ of CRC patients $(35,36)$. The oncogenic role of KRAS in CRC is widely recognized and KRAS mutation is a negative predictor of response to anti-epidermal growth factor receptor antibodies (37). However, the role of KRAS in the response to chemotherapy, particularly the FOLFOX regimen, is less clear. In the present study, KRAS expression in cancer tissues from CRC patients was found to be significantly higher than that in colorectal adenoma and 
normal colorectal mucosa, and the high expression of KRAS predicted poor treatment outcomes in patients.

In summary, the current study provides clinical evidence indicating a negative correlation between PKC $\alpha$ and KRAS expression. Examining the expression of PKC $\alpha$ and KRAS in CRC patients may be of use to guide chemotherapy in the clinical setting. Further clinical study is required to confirm the current findings.

\section{Acknowledgements}

The authors would like to thank Medjaden Bioscience Limited (Hong Kong, China) for assisting in the preparation of this manuscript.

\section{References}

1. Siegel R, Naishadham D and Jemal A: Cancer statistics. 2012. CA Cancer J Clin 62: 10-29, 2012.

2. Fang YJ, Wu XJ, Zhao Q, Li LR, Lu ZH, Ding PR, Zhang RX, Kong LH, Wang FL, Lin JZ, et al: Hospital-based colorectal cancer survival trend of different tumor locations from $1960 \mathrm{~s}$ to 2000s. PLoS One 8: e73528, 2013.

3. Wong RK, Tandan V, De Silva S and Figueredo A: Pre-operative radiotherapy and curative surgery for the management of localized rectal carcinoma. Cochrane Database Syst Rev: CD002102, 2007.

4. André T, Boni C, Navarro M, Tabernero J, Hickish T, Topham C, Bonetti A, Clingan P, Bridgewater J, Rivera F and de Gramont A: Improved overall survival with oxaliplatin, fluorouracil, and leucovorin as adjuvant treatment in stage II or III colon cancer in the MOSAIC trial. J Clin Oncol 27: 3109-3116, 2009.

5. de Gramont A, Figer A, Seymour M, Homerin M, Hmissi A, Cassidy J, Boni C, Cortes-Funes H, Cervantes A, Freyer G, et al: Leucovorin and fluorouracil with or without oxaliplatin as first-line treatment in advanced colorectal cancer. J Clin Oncol 18: 2938-2947, 2000.

6. Kline CL, Sheikh HS, Scicchitano A, Gingrich R, Beachler C, Finnberg NK, Liao J, Sivik J and El-Deiry WS: Preliminary observations indicate variable patterns of plasma 5-fluorouracil (5-FU) levels during dose optimization of infusional 5-FU in colorectal cancer patients. Cancer Biol Ther 12: 557-568, 2011.

7. Micol V, Sánchez-Piñera P, Villalain J, de Godos A and Gómez-Fernández JC: Correlation between protein kinase C alpha activity and membrane phase behavior. Biophys $\mathrm{J} 76$ : 916-927, 1999.

8. Frazer GS: Uterine torsion followed by jejunal incarceration in a partially everted urinary bladder of a cow. Aust Vet J 65: 24-25, 1988

9. Haughian JM and Bradford AP: Protein kinase C alpha (PKCalpha) regulates growth and invasion of endometrial cancer cells. J Cell Physiol 220: 112-118, 2009.

10. Nakashima S: Protein kinase C alpha (PKC alpha): Regulation and biological function. J Biochem 132: 669-675, 2002.

11. Masur K, Lang K, Niggemann B, Zanker KS and Entschladen F: High PKC alpha and low E-cadherin expression contribute to high migratory activity of colon carcinoma cells. Mol Biol Cell 12: 1973-1982, 2001.

12. Fournier DB, Chisamore M, Lurain JR, Rademaker AW, Jordan VC and Tonetti DA: Protein kinase $\mathrm{C}$ alpha expression is inversely related to ER status in endometrial carcinoma: Possible role in AP-1-mediated proliferation of ER-negative endometrial cancer. Gynecol Oncol 81: 366-372, 2001.

13. Koren R, Ben Meir D, Langzam L, Dekel Y, Konichezky M, Baniel J, Livne PM, Gal R and Sampson SR: Expression of protein kinase $\mathrm{C}$ isoenzymes in benign hyperplasia and carcinoma of prostate. Oncol Rep 11: 321-326, 2004.

14. Neill GW, Ghali LR, Green JL, Ikram MS, Philpott MP and Quinn AG: Loss of protein kinase Calpha expression may enhance the tumorigenic potential of Gli1 in basal cell carcinoma. Cancer Res 63: 4692-4697, 2003.

15. Oster $\mathrm{H}$ and Leitges $\mathrm{M}$ : Protein kinase $\mathrm{C}$ alpha but not PKCzeta suppresses intestinal tumor formation in ApcMin/+ mice. Cancer Res 66: 6955-6963, 2006.
16. Lee SK, Shehzad A, Jung JC, Sonn JK, Lee JT, Park JW and Lee YS: Protein kinase C $\alpha$ protects against multidrug resistance in human colon cancer cells. Mol Cells 34: 61-69, 2012.

17. Kranenburg O: The KRAS oncogene: Past, present, and future. Biochim Biophys Acta 1756: 81-82, 2005.

18. McGrath JP, Capon DJ, Smith DH, Chen EY, Seeburg PH, Goeddel DV and Levinson AD: Structure and organization of the human Ki-ras proto-oncogene and a related processed pseudogene. Nature 304: 501-506, 1983.

19. Vogelstein B and Kinzler KW: Cancer genes and the pathways they control. Nat Med 10: 789-799, 2004

20. Lièvre A, Bachet JB, Le Corre D, Boige V, Landi B, Emile JF, Côté JF, Tomasic G, Penna C, Ducreux M, et al: KRAS mutation status is predictive of response to cetuximab therapy in colorectal cancer. Cancer Res 66: 3992-3995, 2006.

21. Hill KS, Erdogan E, Khoor A, Walsh MP, Leitges M, Murray NR and Fields AP: Protein kinase $\mathrm{C} \alpha$ suppresses Kras-mediated lung tumor formation through activation of a p38 MAPK-TGF $\beta$ signaling axis. Oncogene 33: 2134-2144, 2014.

22. Wen-Sheng W: Protein kinase $\mathrm{C}$ alpha trigger Ras and Raf-independent MEK/ERK activation for TPA-induced growth inhibition of human hepatoma cell HepG2. Cancer Lett 239: 27-35, 2006

23. Nitzsche L: Results of radical operation of rectal carcinoma in relation to the tumor size (Dukes' stages A to D). Zentralbl Chir 94: 994-997, 1969 (In German).

24. Mor V, Laliberte L, Morris JN, and Wiemann M: The Karnofsky Performance Status Scale. An examination of its reliability and validity in a research setting. Cancer 53: 2002-2007, 1984

25. Eisenhauer EA, Therasse P, Bogaerts J, Schwartz LH, Sargent D, Ford R, Dancey J, Arbuck S, Gwyther S, Mooney M, et al: New response evaluation criteria in solid tumours: revised RECIST guideline (version 1.1). Eur J Cancer 45: 228-247, 2009.

26. Randall JK and Gilbert JM: Innovations and developments in surgical coloproctology. J R Soc Med 106: 178-183, 2013.

27. Lin YL and Liang JT: FOLFOX4 in the adjuvant treatment of colon cancer in Asian patients. Hepatogastroenterology 59: 400-404, 2012.

28. André T, Iveson T, Labianca R, Meyerhardt JA, Souglakos I, Yoshino T, Paul J, Sobrero A, Taieb J, Shields AF, et al: The IDEA (International Duration Evaluation of Adjuvant Chemotherapy) Collaboration: Prospective Combined Analysis of Phase III Trials Investigating Duration of Adjuvant Therapy with the FOLFOX (FOLFOX4 or Modified FOLFOX6) or XELOX (3 versus 6 months) Regimen for Patients with Stage III Colon Cancer: Trial Design and Current Status. Curr Colorectal Cancer Rep 9: 261-269, 2013.

29. Basu A: The potential of protein kinase $\mathrm{C}$ as a target for anticancer treatment. Pharmacol Ther 59: 257-280, 1993.

30. Kuranami M, Powell CT, Hug H, Zeng Z, Cohen AM and Guillem JG: Differential expression of protein kinase C isoforms in human colorectal cancers. J Surg Res 58: 233-239, 1995.

31. Suga K, Sugimoto I, Ito H and Hashimoto E: Down-regulation of protein kinase $\mathrm{C}$-alpha detected in human colorectal cancer. Biochem Mol Biol Int 44: 523-528, 1998.

32. Gwak J, Jung SJ, Kang DI, Kim EY, Kim DE, Chung YH, Shin JG and Oh S: Stimulation of protein kinase C-alpha suppresses colon cancer cell proliferation by down-regulation of beta-catenin. J Cell Mol Med 13: 2171-2180, 2009.

33. Shimizu K, Goldfarb M, Perucho M and Wigler M: Isolation and preliminary characterization of the transforming gene of a human neuroblastoma cell line. Proc Natl Acad Sci USA 80: 383-387, 1983.

34. Bos JL: Ras oncogenes in human cancer: A review. Cancer Res 49: 4682-4689, 1989.

35. Karapetis CS, Khambata-Ford S, Jonker DJ, O'Callaghan CJ, Tu D, Tebbutt NC, Simes RJ, Chalchal H, Shapiro JD, Robitaille S, et al: K-ras mutations and benefit from cetuximab in advanced colorectal cancer. N Engl J Med 359: $1757-1765,2008$.

36. Amado RG, Wolf M, Peeters M, Van Cutsem E, Siena S, Freeman DJ, Juan T, Sikorski R, Suggs S, Radinsky R, et al: Wild-type KRAS is required for panitumumab efficacy in patients with metastatic colorectal cancer. J Clin Oncol 26: 1626-1634, 2008.

37. Dempke WC and Heinemann V: Ras mutational status is a biomarker for resistance to EGFR inhibitors in colorectal carcinoma. Anticancer Res 30: 4673-4677, 2010. 